\title{
EVALUATION OF ORGANIC AND RECYCLABLE WASTE SEPARATION AT GENERATION SOURCE IN RATNAPURA AND KATARAGAMA LOCAL AUTHORITIES IN SRI LANKA
}

\author{
Naofumi Sato ${ }^{1, \star}$, Chiharu lida ${ }^{1}$, Chiaki Nishi ${ }^{2}$ and Anurudda Karunarathna ${ }^{3}$ \\ ${ }^{1}$ EX Research Institute Ltd., Japan \\ ${ }^{2}$ Kokusai Kogyo Co., Ltd., Japan \\ ${ }^{3}$ Department of Agricultural Engineering, Faculty of Agriculture, University of Peradeniya, Sri Lanka
}
Article Info:
Received:
16 November 2019
Revised:
17 April 2020
Accepted:
5 May 2020
Available online:
30 September 2020
Keywords:
Sri Lanka
3Rs
Biodegradable waste
Recyclable waste
Pilot project

\begin{abstract}
The Japan International Cooperation Agency implemented a technical cooperation project from 2017 to 2019 in collaboration with Central Environmental Authority (CEA) in Sri Lanka. The project provided technical; and financial assistances in preparing solid waste management plans at selected local authorities, and consequently implemented $3 R$ promotion programs introducing source separation at households and subsequent separate collection by local authorities. Two pilot projects were implemented based on the solid waste management plans which were aimed at reducing the amount of solid waste to be landfilled. This paper described the approaches taken and results obtained through the pilot projects in Ratnapura Municipal Council (RMC) and Kataragama Pradeshiya Sabha Town (KPS) of Sri Lanka. The pilot project in RMC consisted of distribution of household compost bins and the separate collection of five categories of waste: 1) biodegradable waste, 2) plastic and polythene, 3) paper and cardboard, 4) glass, metal and coconut shells, and 5) other residual waste; and provision of advices to households by leaflets, distribution of equipment, and implementation of an awareness program. The pilot project in KPS consisted of procurement of separation bins for biodegradable waste by cost-sharing with dischargers and the separate collection of three categories of waste: 1) biodegradable waste; 2) recyclables including paper, cardboard, plastic, polyethylene, iron and coconut shells, broken glass and glass bottles; and 3) other residual waste. The post evaluation of waste composition and final discharge amounts at disposal sites indicated that pilot projects have contributed to increase 3 Rs in both pilot project areas.
\end{abstract}

\section{INTRODUCTION}

Sri Lanka, as a lower-middle income country whose GNI per capita is 3,859 USD in 2017 (World Bank, 2019), is still tackling - and has for several decades - many issues of solid waste management. The total municipal solid waste generation in Sri Lanka is approximately 7,210 tons/day (Basnayake, 2018). Most of the collected waste, including biodegradable waste, ends up in 300 or more number of open dump sites or primary landfill sites scatted around the country. The dumpsites are often less than one hectare in area and lack proper landfill components such as leachate, emission and groundwater contamination control measures.

In Sri Lanka, the National Strategy for Solid Waste Management was formulated in 2000 and it recommends solid waste management be conducted as follows:

- Prioritise waste avoidance and reduction over the next stage of waste recycling and other forms of environmentally-sound disposal,

- Reuse unavoidable waste as much as possible,

- Maintain the content of hazardous substances in waste at the lowest possible level, and

- Guarantee an environmentally sound residual waste treatment and disposal as basic prerequisites for human existence.

Furthermore, the National Policy on Solid Waste Management was formulated in 2007 and it defines the environmental accountability and social responsibility of all waste generators, waste managers and service providers and aims to actively involve individuals and all relevant parties in integrated and environmentally-sound solid waste management practices. On the other hand, the Sri Lankan Government prioritises appropriate and sustainable SWM - a Ten-year Horizon Development Framework (2006- 
2016) - and identifies the importance of the promotion of the 3Rs (reduce, reuse, recycle) and the establishment of environmentally-friendly final disposal sites for a sustainable SWM system.

Several engineered landfill sites have been established and are operating since the early 2000s and one sanitary landfill at DOMPE site in Western Province has been operated by the CEA since 2014 . The lifetimes of the engineered landfill sites and sanitary landfill site are limited due to shortage of capacity and high waste discharge amounts. In order to improve and upgrade present open dumps, the technical, economic, social and institutional aspects of local authorities need to be fully taken into account in Sri Lanka (Zurbrugg, 2003). Incinerators are not used as a solution for municipal solid waste at the moment. Since the recycling system does not function properly, it is estimated that waste recycling rate is less than $3 \%$ in Sri Lanka (JICA, 2019). This means that most recyclable waste ends up merely being disposed of at landfill sites without being processed for recycling. To solve these issues, the Sri Lankan government intends to develop more sanitary landfill sites and new incineration plants. In addition, 3Rs have been promoted by local authorities for a few years to implement proper waste management practices, such as waste reduction at generation source, waste segregation of biodegradable waste and recyclable waste, and intermediate treatment. However, the effectiveness of 3R activities seems limited at some local authorities that mainly concentrate on the segregation of recyclable waste rather than biodegradable waste.

To support the efforts of the Sri Lankan Government, the Japan International Cooperation Agency (JICA) implemented the technical cooperation project, Experts in Pollution Control and Reduction of Environmental Burden in Solid Waste Management (ReEB Waste), from 2017 to 2019 in cooperation with CEA. ReEB Waste assisted preparing solid waste management action plans at local authorities and implemented 3R promotion programs involving solid waste separation and collection pilot projects aimed at reducing the amount of landfilled solid waste generated in target areas in Ratnapura Municipal Council (RMC) in Sabaragamaua Province and Kataragama Pradeshiya Sabha (KPS) town in Uva Province. Moreover, ReEB Waste also implemented pilot projects for rehabilitation of current disposal sites to mitigate environmental issues with locally available, low-cost materials and low-maintenance techniques in Kurunegala Municipal Council in North Western Province and KPS. The selection of cities for strengthening the capacity of local authority to implement source segregated waste collection was based on several criteria such as absence of effective source segregation, level of urbanization, strategic importance for dissemination of good practices, and willingness of local authority for improvement.

The following case studies describe the results and evaluation of biodegradable and recyclable waste separation at generation source in RMC and KPS under the pilot projects of $3 \mathrm{R}$ promotion by ReEB Waste.

\section{PILOT PROJECT AT RATNAPURA MUNICI- PAL COUNCIL (CASE STUDY 1)}

\subsection{Overview of Ratnapura Municipal Council}

\subsubsection{Outline of Ratnapura Municipality}

Ratnapura Municipality has a population of around 54,000 (in 2016 (JICA, 2019)), 12,931 households and is the capital of Sabaragamuwa Province, Sri Lanka. Ratnapura city centre is $101 \mathrm{~km}$ southeast of the Sri Lankan capital of Colombo. Ratnapura is the major commercial and services hub of Ratnapura District, as well as the only local authority with municipal status in Sabaragamuwa Province, Sri Lanka. Ratnapura has a renounced gem industry and education institutions, with many popular schools and tuition centres. Ratnapura City is also a major transit hub in Sri Lanka, connecting Sabaragamuwa, Eastern and Southern provinces.

\subsubsection{Baseline study in RMC}

In 2017, a baseline study on waste management practices was conducted in RMC area to understand the baseline conditions of in RMC. The baseline information was gathered from series of activities; a structured questionnaire survey from 156 randomly selected households, interview surveys from 55 business and institutes, questionnaire survey in 6 recycling businesses, a waste composition and quantity survey at disposal site, waste material flow inventory survey at resource recovery center (composting and recyclable collection) of RMC. The baseline research revealed that RMC collects two categories of waste,biodegradable and non-biodegradable waste; however, the collected waste was directly dumped at an open dumping site (Kanadola site, owned by RMC).

The baseline study further revealed that waste generation is 53.76 ton per day, while waste collection amount is only 47.6 ton per day in which 47.3 ton of waste disposes at dumpsite. The per capita waste generation rate is 0.537 $\mathrm{kg}$, and the bulk density of collected waste is $0.372 \mathrm{ton} /$ $\mathrm{m}^{3}$ with moisture content of $43-55 \%$. The waste composition resulted from baseline study is illustrated in Figure 1. The waste composition in 2017 showed that $57 \%$ of the total waste is biodegradable (kitchen waste, grass \& wood waste), while $32 \%$ is inorganic recyclable waste and $11 \%$ is residue. In comparison, a study conducted in Kandy city that is the capital of Central Province, showed that $75 \%$ of its total municipal waste was biodegradable waste with $13 \%$ recyclable waste and $12 \%$ other waste (JST-JICA, 2016).

Though waste collected by RMC has greater fraction of recyclable waste, the resource recovery was limited to scavenging on non-biodegradable waste by collection crew at the disposal site. There was a small box composting facility (about 2 ton/day) which was merely enough to handle organic waste collected from vegetable market (JICA, 2017); thus, biodegradable waste from residential and commercial premises disposed at open dumpsite. Eventually, biodegradable and other mixed waste dumped at Kanadola caused serious environmental issues such as leachate generation, vermin and offensive odours. Consequently, SWM action plan was developed in which expansion of composting system was recommended to handle 


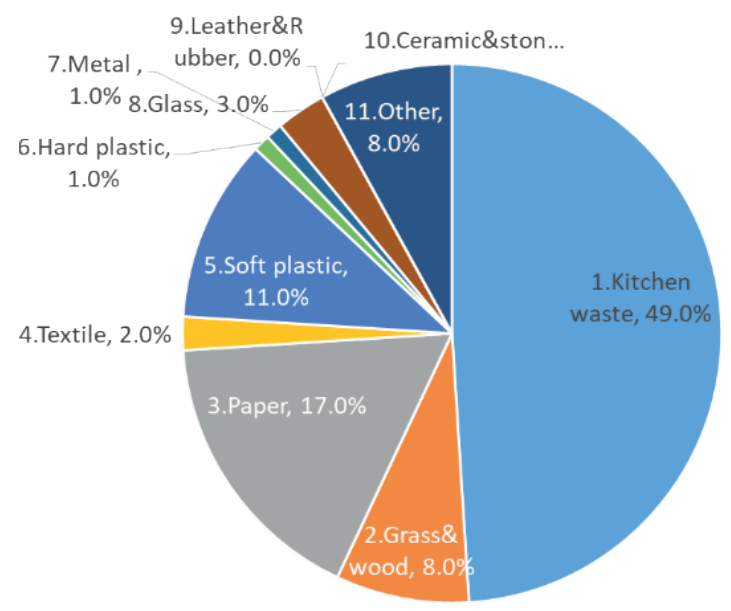

FIGURE 1: Waste composition in RMC (2017).

biodegradable waste from residential and commercial sectors.

\subsection{Method of RMC pilot project}

\subsubsection{Area of RMC pilot project}

The baseline study revealed that RMC area is consisted of 16 villages which are further amalgamated to four waste collection zones. Consequently, four villages were selected to implement source segregation pilot programs; Batugedara village (high and middle income households), Town North (commercial centre), Kospalawinna village (multi ethnic) and Muwagama village (middle and low income) based on their unique characteristics. As summarised in Table 1, the pilot project covered approximately a quarter of all households in RMC. According to the SWM action plan of RMC (2018-2022), prepared with the assistance of ReEB
TABLE 1: Numbers of households of the pilot project in RMC.

\begin{tabular}{c|c} 
Area name & Household \\
\hline Batugedara & 423 \\
\hline Town North & 698 \\
\hline Kospalawinna & 1,158 \\
\hline Muwagama & 514 \\
\hline Total & 2,793 \\
\hline
\end{tabular}

Waste, experiences in the first year (2018) were planned to be carried over to the second year (2019) to enable the expansion of solid waste separation and collection to the whole city to be completed in 2019 , as planned.

\subsubsection{RMC pilot project activities}

The SWM situation before, the expected situation after the implementation of pilot project in December 2017 and the activities of the project are shown in Table 2. The pilot project increases separation categories from two (biodegradable and non-biodegradable) to five (Biodegradable waste, Plastic and polythene, Paper and cardboard, Glass, metal and coconut shells, other residuals). The project distributed appropriate containers for each waste generators; green colour plastic waste collection bins for biodegradable waste and different colour polysack bags for other non-degradable wastes. PHIs (Public Health Inspectors) and supervisors in RMC explained the new waste separation categories, ways to discharge (i.e. use of the distributed green-coloured bins and bags), and collection dates to residents and commercial premises. Household composting was promoted in pilot project areas expecting to increase the percentage of home composting from $6 \%$ to $10 \%$. RMC identified 250 households in four (4) pilot project areas and distributed 250 home compost bins (Batugeda-

TABLE 2: Situation before and after the pilot project, and overview of activities in the project in RMC.

\begin{tabular}{|c|c|c|c|}
\hline Stage of Solid Waste Management & $\begin{array}{l}\text { Before pilot project } \\
\text { (before December 2017) }\end{array}$ & Expected situation (2018) & Overview of activities \\
\hline Generation & $\begin{array}{l}\text { Two separation categories } \\
\text { Biodegradable (Mixed waste) } \\
\text { - Non-biodegradable (Recyclable } \\
\text { waste) }\end{array}$ & $\begin{array}{l}\text { Five separation categories } \\
\text { - } \text { Biodegradable waste } \\
\text { - Plastic and polythene } \\
\text { - } \text { Glass, metal and coconut shells } \\
\text { - Others }\end{array}$ & \multirow{2}{*}{$\begin{array}{l}\text { Creation of leaflet and notice } \\
\text { board } \\
\text { Awareness raising programme } \\
\text { (door-to-door explanation, } \\
\text { community meeting and school } \\
\text { programme) } \\
\text { Procurement and distribution of } \\
\text { separation bins ( } 3,000 \text { January, } \\
3,200 \text { in June and } 1,940 \text { in Octo- } \\
\text { ber } 2018), \text { poly sack bags }(9,000 \\
\text { January, 9,600 in June and } 5,820 \\
\text { in October 2018) } \\
\text { Monitoring }\end{array}$} \\
\hline Discharge & $\begin{array}{l}\text { No specific announcement by RMC } \\
\text { (Shopping bag was being used } \\
\text { mainly by residents and commer- } \\
\text { cials) }\end{array}$ & $\begin{array}{l}\text { Green (residents only) sepa- } \\
\text { ration bin for biodegradable } \\
\text { wastes. } \\
\text { Three different coloured poly } \\
\text { sack bags for recyclable wastes } \\
\text { (residents only) } \\
\text { Any bag for other waste }\end{array}$ & \\
\hline Collection and transportation & $\begin{array}{l}\text { Tractor for biodegradable waste } \\
\text { Three-wheeler and crew cab for } \\
\text { non-biodegradable waste }\end{array}$ & $\begin{array}{l}\text { Tractor and three-wheeler with } \\
\text { large collection bins installed for } \\
\text { biodegradable waste } \\
\text { Three-wheeler and crew cab } \\
\text { for recyclable wastes and other } \\
\text { wastes }\end{array}$ & $\begin{array}{l}\text { Procurement of a three-wheeler, } \\
\text { large collection bins and GPSs } \\
\text { Revision of collection and tran- } \\
\text { sportation plan } \\
\text { Monitoring }\end{array}$ \\
\hline Treatment and Disposal & $\begin{array}{l}\text { Vegetable waste for composting } \\
\text { by box compost system } \\
\text { Recovered recyclable wastes } \\
\text { for sale } \\
\text { Biodegradable waste (mixed } \\
\text { waste) for dumping } \\
\text { Lack of monitoring data }\end{array}$ & $\begin{array}{l}\text { Biodegradable wastes for com- } \\
\text { posting by expansion of windrow } \\
\text { compost yard } \\
\text { Recovered recyclable wastes } \\
\text { for sale } \\
\text { Monitoring of treated and dispo- } \\
\text { sed waste amount }\end{array}$ & $\begin{array}{l}\text { Establishment of windrow com- } \\
\text { posting system } \\
\text { Establishment of monitoring } \\
\text { system at the site }\end{array}$ \\
\hline
\end{tabular}


ra: 48, Town North: 32, Kospalawinna: 90, Muwagama: 80 ) in March 2018, to those who: were willing to compost at home, had sufficient space, and/or had difficulty receiving waste collection services due to inaccessibility of collection vehicles. Information sessions (small-group meetings) were held at the time of distribution of home compost bins. The awareness focused on disseminating knowledge on home composting techniques such as: where to locate the bin, appropriate types and combinations (carbon: nitrogen ratio) of waste, appropriate waste moisture level, demarcation with Jeewakottu (traditional home composting), as well as troubleshooting for issues such as malodours and insects breeding.

ReEB Waste procured a three-wheeler (with large bins installed) to collect biodegradable waste from the narrow streets that are inaccessible by normal waste collection tractors. The in-house human resource capacity building was conducted by training for staff of RMC including supervisors, collectors, drivers and disposal site workers. In addition to the above mentioned activities in the target areas, the project also expanded the composting facility to a windrow system (15 tons/day) and regularized waste collection inventory recording at the Kanadola site to monitor the amount of waste received and disposed of.

There were no additional staff or workers hired for the pilot project. The following human resources were assigned to solid waste management department of RMC from September 2017 to March 2019: 150-160 collection workers, 20 drivers, one medical officer of health, five public health inspectors, and 20 field supervisors. All the awareness raising programmes, monitoring activities and surveys in the pilot project were conducted solely by these RMC staff.

\subsection{Results of RMC pilot project and discussion}

2.3.1 Changes in waste amounts resulting from RMC pilot project

Waste collection amount did not considerably change during the pilot project from 1,050.0 ton/month in January 2017 to $1,085.0$ ton/month in March 2019. The total amount of waste disposed at open dump declined from 979.6 ton/month in December 2017 to 682.0 ton/month in March 2019 after implementing the pilot project in December 2017 (Figure 2). Contrarily, the collection of biodegradable waste increased from 77.5 ton/month in December 2017 to 325.5 ton/month in March 2019 while the amount of recyclable waste increased from 27.9 ton/month to 77.5 ton/month for the same period. The sequential changes of waste collection amounts in RMC from 2017 to 2019 is illustrated in Figure 2.

\subsubsection{Change to waste separation percentage resulting from RMC pilot project}

The effectiveness or neatness of biodegradable waste separation at household level was estimated by analysing

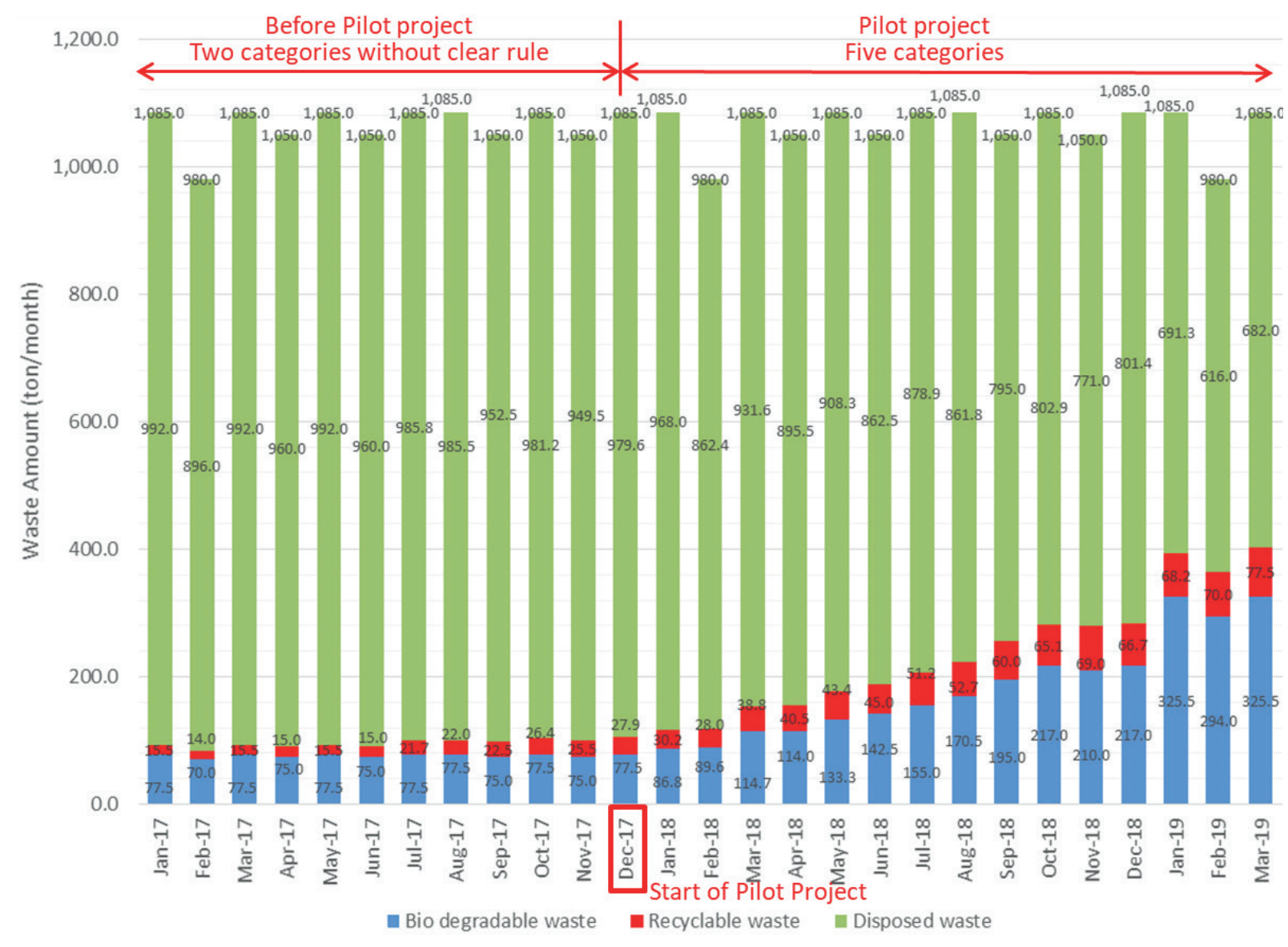

FIGURE 2: Waste amount in RMC from 2017 to 2019. 
the composition of biodegradable waste collection before (September 2017) and after the project implementation (July 2018), and is illustrated in Figure 3. The results showed that amount of non-biodegradable waste in biodegradable collection was $39.9 \%$ in 2017 ; however, significantly reduces to $1.7 \%$ in July 2018 after implementing the pilot project. Figure 4 shows increasing recovery of recyclable waste fraction from $69.2 \%$ in July 2018 to $79.7 \%$ in November 2018, due to sorting of non-degradable waste in to five categories. Thus, the pilot project activities contributed to improve the waste separation percentage within the biodegradable waste category as well as in the five categories of recyclable waste.

\subsubsection{Outcome of the pilot project}

In RMC, the pilot project was conducted based on the 2018-2022 SWM action plan, which was developed cooperatively by the ReEB Waste and RMC. Table 3 shows the targets of the action plan and the results thereof. The target number of households home composting was achieved by distributing 250 compost bins in the ReEB Waste project. The average amount of separated biodegradable waste received at the Kanadola site dramatically increased from 2.3 ton/day in 2017 to 5.1 and 10.5 ton/day in 2018 and 2019

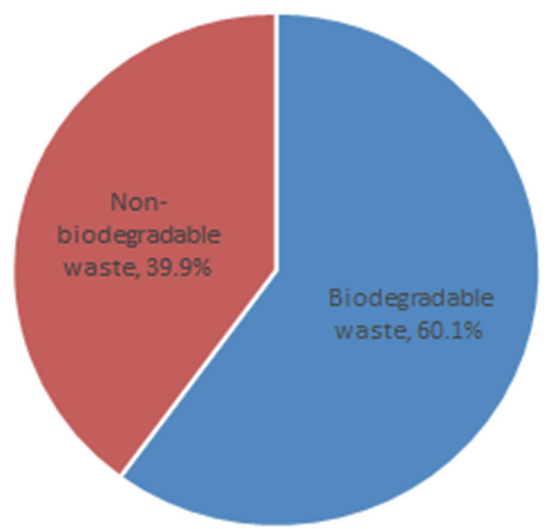

September 2017

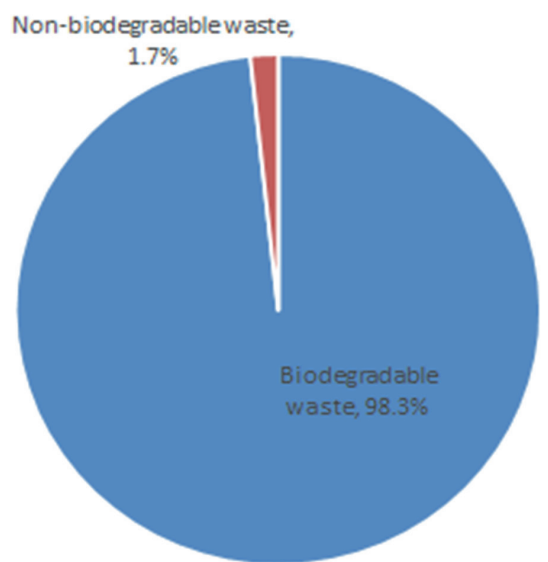

July 2018

FIGURE 3: Waste separation percentage between biodegradable waste and non-biodegradable wastes of "biodegradable waste" separation category. respectively - which met the targets of the action plan. Though higher amount of recyclables collected in 2017 was higher due to poor quality of source separation, the quality of separated recyclables increased from 2018 to 2019. Increase of capacity of centralised composting facility considerably decreases the amount of waste disposed at final disposal site from 35.8 ton/day in 2017, to 28.7 ton/ day and 22.1 ton/day in 2018 and 2019, respectively.

\subsubsection{Discussion}

The main reason for the reduction of final disposal amount of waste in the RMC pilot project was that biodegradable waste, which accounts for the largest proportion of waste generation, was thoroughly separated at the generation source and intermediately treated by centralized composting. By preferentially separating biodegradable waste at the generation source, the handling of recyclable waste became easier, and as a result, the amount of recyclable waste separated at the generation source also increased. It was found that distribution of separate bins for biodegradable waste and bags for recyclable waste and thorough implementation of separation, discharge and collection rules increases the effectiveness of source separation. RMC had a sufficient financial allocation and human

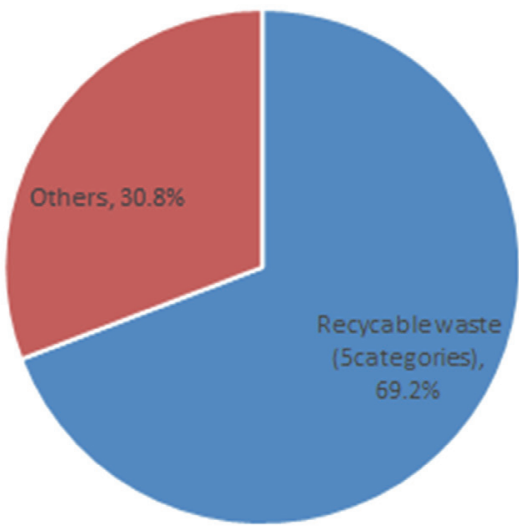

July 2018

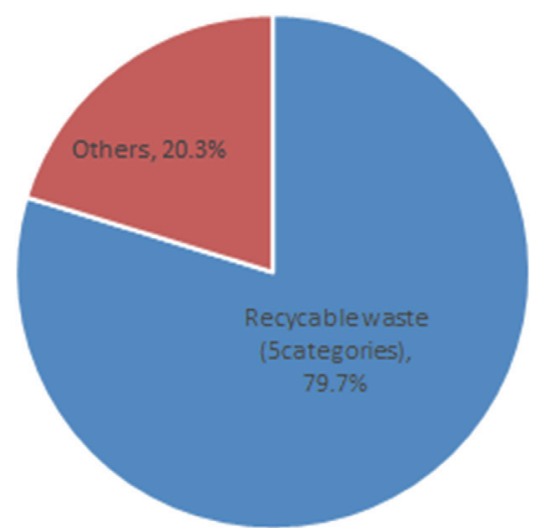

November 2018

FIGURE 4: Waste separation percentage between recyclable waste and others wastes of " 5 categories recyclable waste" separation category. 
TABLE 3: Targets of Action Plan for RMC and results

\begin{tabular}{|c|c|c|c|c|c|c|}
\hline \multirow[b]{2}{*}{ Items } & \multirow[b]{2}{*}{2017} & \multicolumn{2}{|c|}{2018} & \multicolumn{2}{|c|}{2019} & \multirow{2}{*}{$\begin{array}{r}2022 \\
\text { Targe }\end{array}$} \\
\hline & & Target & $\begin{array}{c}\text { Result in } \\
\text { November }\end{array}$ & Target & $\begin{array}{c}\text { Result in } \\
\text { March }\end{array}$ & \\
\hline Percentage of households doing home composting (\%) & 6.0 & 6.9 & 6.9 & 8.0 & NA & 10 \\
\hline Receiving amount of biodegradable waste at the site (ton/day) & 2.3 & 5.3 & 5.1 & 8.6 & 10.5 & 15 \\
\hline Compost production at the site (ton/month) & 2.3 & 5.3 & 2.5 & 8.6 & 4.2 & 15 \\
\hline Receiving amount of recyclable items at the site (ton/day) & 2.9 & 3.7 & 1.6 & 4.9 & 2.9 & 14.9 \\
\hline Final disposal amount (ton/day) & 35.8 & 35.3 & 28.7 & - & 22.1 & 20.1 \\
\hline
\end{tabular}

resources for solid waste management, so it was possible to simultaneously instruct the source separation of biodegradable waste and recyclable waste into five categories.

\section{PILOT PROJECT AT KATARAGAMA PRA- DESHIYA SABHA (CASE STUDY 2)}

\subsection{Overview of Kataragama Pradeshiya Sabha}

\subsubsection{Outline of KPS}

Kataragama is a township with a population of 22,640 (in 2017 (JICA, 2019)) located in the southern-most part of Uva Province on the island of Sri Lanka and borders the Yala National Park. The town is home to one of the most important holy sites in Sri Lanka and pilgrims and tourists from all over the country and overseas gather for the annual Perahera festival (religious procession) held over two weeks in July/August.

\subsubsection{Baseline study in KPS}

In 2017, a baseline study on waste management practices was conducted in KPS area to understand the baseline conditions of in KPS. The baseline information was gathered from series of activities; a structured questionnaire survey from 161 randomly selected households, interview surveys from 62 business and institutes, questionnaire survey from one recycling businesses, a waste composition and quantity survey at disposal site, waste material flow inventory survey at resource recovery centre (composting and recyclable collection) of KPS.

The baseline study revealed that the most serious issue is the management of final disposal site in Galapitiyaya, which, although permitted to be used for landfill site by the government, was operated in an open dumping manner. The site locates within a reserve forest, thus wild animals, especially elephants frequently scavenge at the site. Moreover, waste generation during the festival season increase by two times of daily average and eventually KPS opt to dispose waste in temporally dumpsites along the river. According to a survey conducted by a JICA study, the waste collection amount was approximately 3.5 ton per day in 2015 (JICA, 2016). The study further revealed that the waste generation rate was $0.620 \mathrm{~kg}$ per capita, while the bulk density of collected waste was $0.598 \mathrm{ton} / \mathrm{m}^{3}$ and moisture content was $43-55 \%$. By the time ReEB Waste started, KPS had established a small resource recovery facility with a box composting system and recyclable sorting and bailing machine. However, there were no clear rules or advices given to waste generators on segregation. The survey showed that out of total, $57.3 \%$ was kitchen waste; however more than a half $(32.7 \%)$ of kitchen waste was in non-biodegradable waste collection due to ineffective separation at source. This indicated that the waste separation at source was not effectively practiced by generators. For reference, in the neighbouring municipality of Hambantota, $54 \%$ of its total waste was biodegradable waste, $6 \%$ was recyclable waste and 40\% was other waste in 2016 (JST-JICA, 2016). In another neighbouring municipality, Kalumunai, $71 \%$ of its total waste was biodegradable waste, $16 \%$ recyclable waste and 17\% other waste in 2010 (Ariyawansha et al., 2010).

The waste composition in KPS is illustrated in Figure 5.

\subsection{Method of KPS pilot project}

\subsubsection{Area of KPS pilot project}

The baseline study revealed that KPS area is consisted of 5 villages and two main townships, Kataragama and Sella-Kataragama which are $5 \mathrm{~km}$ apart. The KPS area had been divided to six waste collection zones. Two of the six waste collection zones in KPS, Zone 3 and Zone 4, were targeted in the pilot project. In Zone 3, 52 guesthouses/hotels and shops are receiving waste collection service. Zone 3 is close to two popular Hindu temples and has small market areas where shops sell souvenirs and offerings (flowers and fruits) to tourists. Waste collection in Zone 4 covers 64 households and 54 guesthouses/hotels and small shops. Zone 4 is close to the city-centre of KPS.

\subsubsection{KPS pilot project activities}

KPS took a two-step approach to establish an effective source segregation program. The first step was started in November 2017, and the aim was to fully establish a two-category separation system where biodegradable waste and other waste would be separated. This involved disseminating waste separation rules to generators by distributing a leaflet to every household and business, holding community meetings, and organizing field visit for community members to KPS's compost facility. Appropriate waste collection bins, 20-liter bins for households and 45-liter bins for guesthouses/hotels, were distributed to every household and businesses. New waste collection schedule was introduced where collection vehicle collects degradable and non-degradable waste on alternate days. KPS assigned a designated field staff in each zone to follow the collection vehicles to monitor implementation and to correct any malpractice.

After the two-category separation had become well established, second step started in July 2018 to separate 


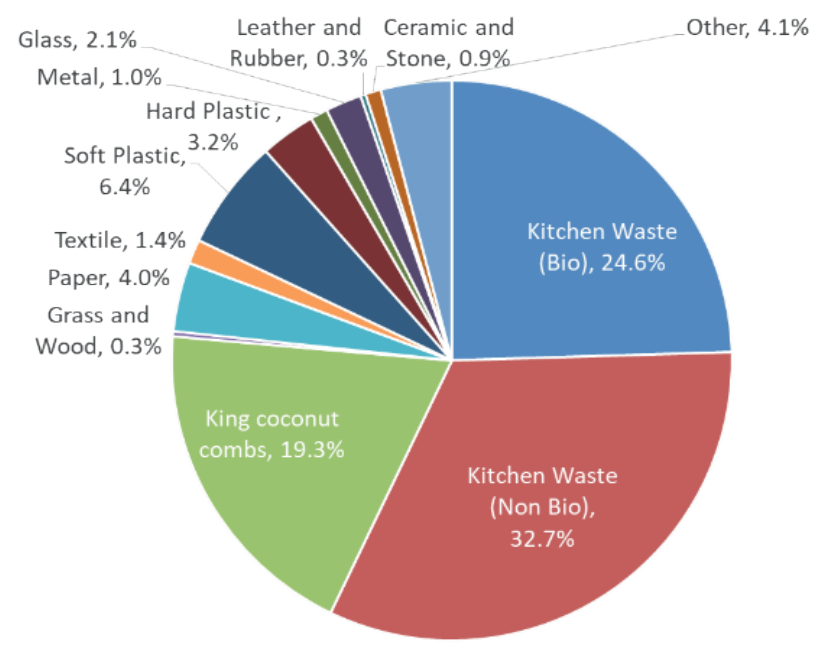

FIGURE 5: Waste composition in RMC (2017).

waste into three categories: biodegradable waste; valuable recyclable that can be sold through identified dealers which include cardboard, metal cans, hard plastics, plastic drink bottles (PET), glass, paper (newspaper, magazines, dry and clean paper) and coconut shells; and other residual waste. The residual waste has is to be disposed at final disposal site.

At the onset of launching the second step, the waste collection schedule was revised. Collection vehicles are sent to each zone on Monday, Wednesday, Thursday, and Sunday for biodegradable waste; Thursday to Zone 4 and on Sunday to Zone 3 for valuable recyclable collection, and other days for residual waste collection. Another leaflet which explains the separation categories and collection schedule was distributed through door-to-door visits. During Step 2 implementation, the newly upgraded landfill opened in September 2018 and representatives of the community were also invited to the opening ceremony to keep them informed of how the waste separated by residents would be treated. All waste collection staff and drivers were trained on waste segregation thus they were instrumental in taking the message to residents on correct source separation at source. Table 4 shows the waste management condition prior to launching the pilot project (2017), project expectations after implementation, and the activities of the project.

During the implementation of the pilot project, ReEB Waste made several inputs towards achieving the project aims amongst residents in target communities, including: organization of awareness activities such as community meetings, house-to-house visits for distributing leaflets and compost site visits; and distribution of 45-liter (to businesses) and 20-liter (to households) bins for separately discharging biodegradable waste. Twenty-five 45-liter bins were distributed in February 2018 to Zone 3 (predominantly guesthouses), and 15 bins were distributed to Zone 4 in June 2018, followed by a further 10 bins in 2019 in response to individual requests in zones 1,3 and 4 . Forty-two 20-liter bins were distributed in March 2018 and a further three in January 2019 to households in Zone 4.

\subsection{Results of KPS pilot project and discussion}

3.3.1 Changes to waste amounts due to festivals and management issues

Total amount of waste collected by KPS from 2017 to 2019 and changes in waste separation are shown in Figure 6 . It should be noted that KPS hosts a large pilgrim/tourist population during the Perahera festival season in July and August every year and the average monthly amount of waste discharged almost doubles during the festive period compared to the first half of the year. The monthly average

TABLE 4: Situation before and after the pilot project, and overview of activities in the project in KPS.

\begin{tabular}{|c|c|c|c|}
\hline Stage & $\begin{array}{l}\text { Before pilot project } \\
\text { (before December 2017) }\end{array}$ & Expected situation & Overview of activities \\
\hline Generation & $\begin{array}{l}\text { - Two separation categories in some are- } \\
\text { as } \\
\text { - Biodegradable } \\
\text { - Non-biodegradable (mixed waste) } \\
\text { - No separation in some areas } \\
\text { - Mixed waste }\end{array}$ & $\begin{array}{l}\text { - Step 1: two-category separation } \\
\text { - } \text { (November 2017-) } \\
\text { - Biodegradable waste } \\
\text { - } \text { Others } \\
\text { - Step 2: three-category separation } \\
\text { - } \quad \text { (July 2018-) } \\
\text { - Biodegradable waste } \\
\text { - Recyclables } \\
\text { - Other waste (going to disposal site) }\end{array}$ & \multirow[t]{2}{*}{$\begin{array}{l}\text { Creation of leaflet and notice board } \\
\text { door explanation, community meeting } \\
\text { and school programme) } \\
\text { - Procurement and distribution of biode- } \\
\text { gradable separation two types of bins: } \\
\text { 20-liter for household and } 45 \text { litre for } \\
\text { guesthouse } \\
\text { - Procurement and distribution of com- } \\
\text { post bins } \\
\text { - Monitoring }\end{array}$} \\
\hline Discharge & - No specific announcement by KPS & $\begin{array}{l}\text { Both } 20 \text { litre and } 45 \text { litre bins for biode- } \\
\text { gradable waste have a lid to mitigate the } \\
\text { smell of waste and keep animals away. } \\
\text { Any bag for other waste }\end{array}$ & \\
\hline $\begin{array}{l}\text { Collection and } \\
\text { transportation }\end{array}$ & $\begin{array}{l}\text { Tractor for biodegradable waste and mi- } \\
\text { xed waste }\end{array}$ & $\begin{array}{l}\text { Modified tractor with installed partition } \\
\text { for separation of categorised waste. }\end{array}$ & $\begin{array}{l}\text { - Training for collection staff and drivers } \\
\text { to recognise the separation categories } \\
\text { - Revision of collection and transportation } \\
\text { plan } \\
\text { - Monitoring }\end{array}$ \\
\hline $\begin{array}{l}\text { Treatment and } \\
\text { Disposal }\end{array}$ & $\begin{array}{l}\text { - Vegetable waste for composting by box } \\
\text { compost system } \\
\text { - Recovered recyclable wastes for sale } \\
\text { Biodegradable waste (mixed waste) for } \\
\text { dumping } \\
\text { - Lack of monitoring data }\end{array}$ & $\begin{array}{l}\text { Biodegradable wastes for composting } \\
\text { by expansion of windrow compost yard } \\
\text { Recovered recyclable wastes for sale } \\
\text { - Monitoring of treated and disposed wa- } \\
\text { ste amount }\end{array}$ & $\begin{array}{l}\text { Establishment of windrow composting } \\
\text { system } \\
\text { - Installation and operation of weigh brid- } \\
\text { ge at compost plant } \\
\text { Establishment of monitoring system at } \\
\text { the site }\end{array}$ \\
\hline
\end{tabular}




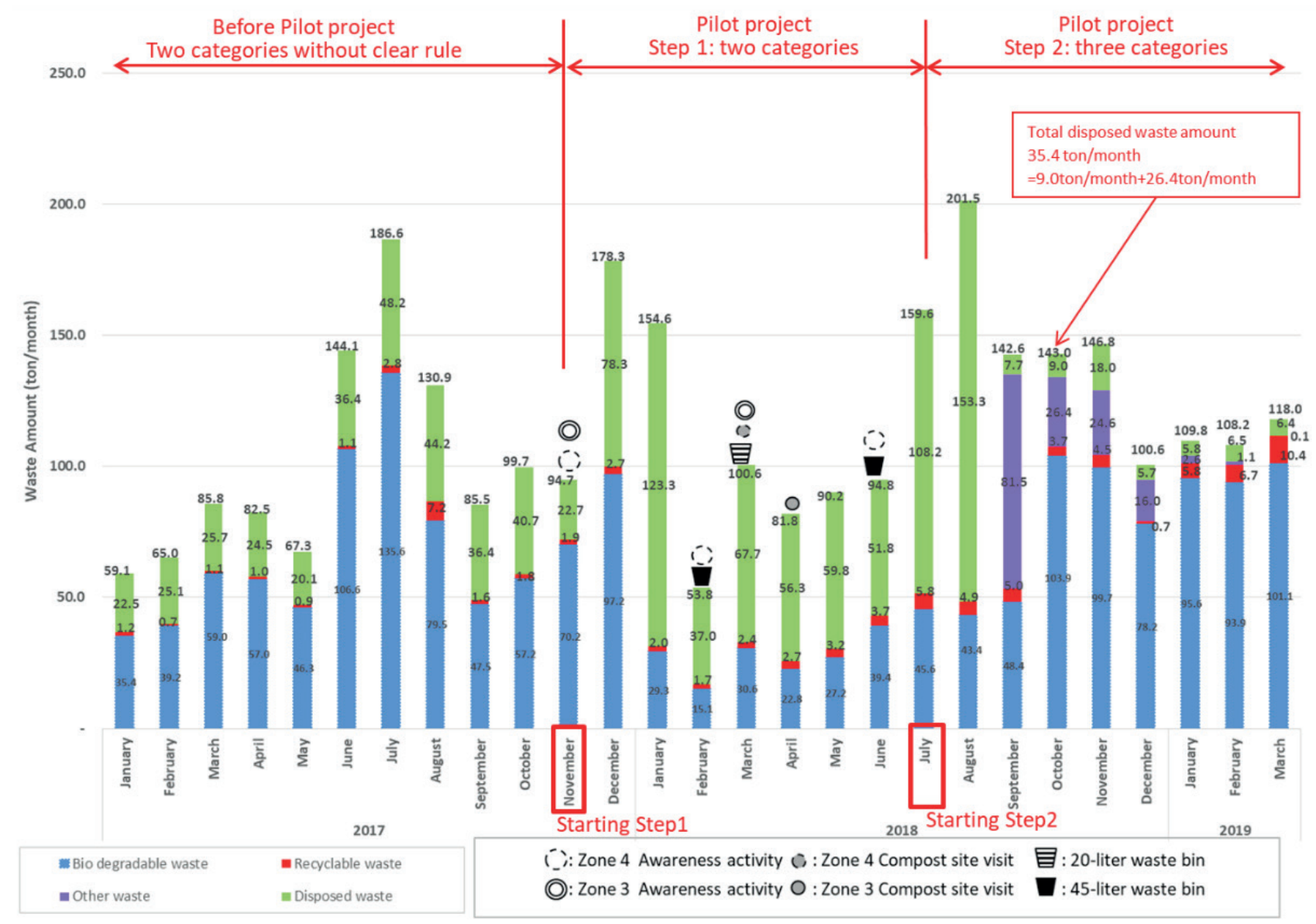

FIGURE 6: Waste amount in KPS from 2017 to 2019.

amount for the first half of 2017 was 84.0 ton/month, while the monthly average for July and August 2017 was 158.8 ton/month. The monthly average amount for the first half of 2018 was 96.0 ton/month, while the monthly average for July and August 2018 was 180.6 ton /month. Moreover, since extra solid waste was taken to KPS from some other local authorities in December 2017 and January 2018, the total waste amount was higher than the normal condition in December and January. On the other hand, number of temporally collection workers decreased by 5 workers (out of 26) from February to June 2018 due to internal management issues at KPS. The labour shortage led to lower the efficiency of overall waste collection in KPS area as well as the efficiency of recycling facility. Consequently, the total waste collection and biodegradable waste collection decreased and the waste disposed to the final disposal site increased, despite the pilot project being implemented. Therefore, in this paper, the impact of the pilot project on waste reduction is analysed excluding the record for July and August each year and for December 2017 to June 2018.

\subsubsection{Changes in waste amounts resulting from KPS pilot project}

Comparing the amounts of discharged waste during the three months from January to March 2017 (before the pilot project) and the amounts in the same three months in 2019 , the amounts of discharged waste increased from
59.1 ton/month to 109.8 ton/month in January, from 65 ton/month to 108.2 ton/month in February and from 85.8 ton/month to 118.0 ton/month in March. KPS did not make any specific changes to expand their waste collection services, thus these increases can be considered as changes in the discharge manner of residents.

Biodegradable waste amount and recyclable waste amount show steady increases during the first half of 2017. In November 2017 (start of the pilot project), the biodegradable waste collection was 70.2 ton/month that increased to 99.7 ton/month in November 2018 at the end of the Step 2. Amount of recyclable waste collection steadily increased from 1.9 ton/month in November 2017 to 4.5 ton/month in November 2018. The increase of biodegradable and recycling waste resulted a decrease in mix waste disposal from 81.5 ton/month at the beginning in September 2018 to 24.6 ton/month in November 2018. Amount of waste disposed at final disposal site decreased from 40.7 ton/month in October 2017 to 35.4 ton/month in October 2018,. The further decrease of final disposal amount occurred after December 2018 is due to expansion of three-category separate collection scheme to other collection zones.

\subsubsection{Changes to waste separation percentages resulting from KPS pilot project}

Before and during the pilot project waste composition surveys were conducted three times: first in October 2017, 
before the pilot project; second in June 2018, during Step 1; and third in November 2018, during Step 2. These surveys measured the composition of the waste collected separately as "biodegradable" and "non-biodegradable (or other)" wastes from Zone 3 and Zone 4.

Before the implementation of the pilot project, during the collection and loading to vehicle, collection workers separated the unsorted waste as biodegradable and other waste by opening the waste bags. Thus, the waste brought into the compost site was already separated into two categories; however, present in two comportment separated by a wooden flange in tractor trailer. At the first stage of pilot project, new collection method was introduced where only one type of waste is collected during collection, the other type of waste is collected separately in another trip or else another day. On the other hand, slowly degradable organic waste such as hardwood, coconut shells and fibrous banana stems were categorised as other waste that to be disposed at landfill. Furthermore, residents did not allow to dispose garden waste and tree trimmings along with biodegradable waste due to bulkiness, thus only kitchen and food waste were received at composting site. Recognizing the importance of having dry and bulky organics for composting process, at the second stage of project, a small shredding machine was installed at composting facility to reduce the size of garden waste and tree trimmings. Once the shedding machine was installed, KPS started to accept garden waste and tree trimmings, which can be discharged together with kitchen waste. The composition changes in biodegradable waste in Zone 3 and Zone 4 are illustrated in Figure 7 and Figure 8 respectively.

During Step 1, valuable recyclables were not collected separately but mix with the other residual waste that cannot be taken to composting facility. However, since a private recyclable collection business had started to collect valuable recyclables in parallel to first stage pilot project implementation, the composition survey showed that amount of valuable recyclables are low (2018). By the third quarter of 2018, KPS implemented collection of valuable recyclables on a designated day of the week, consequently the composition survey in 2018 showed that the non-biodegradable waste was mainly consisted of plastic films due to effective diversion of garden waste and valuable recyclables for resource recovery.

At the end of Step 1 (at the time of the second waste composition survey), the percentage of kitchen waste was small in other waste, and no kitchen waste or garden waste was found mixed in other waste by the end of Step 2 (at the

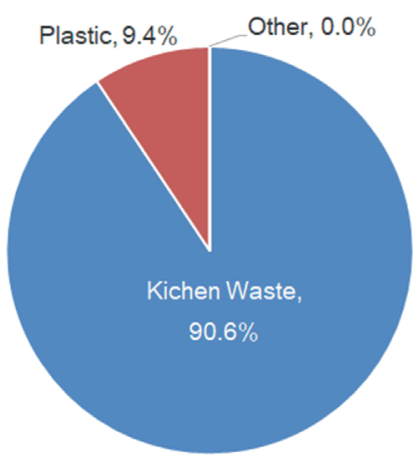

October 2017 (before pilot project)

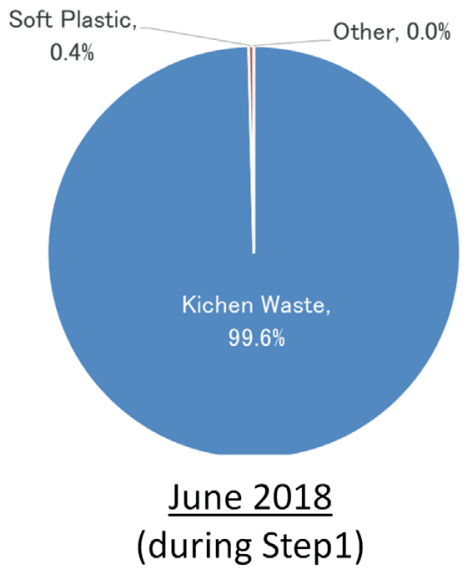

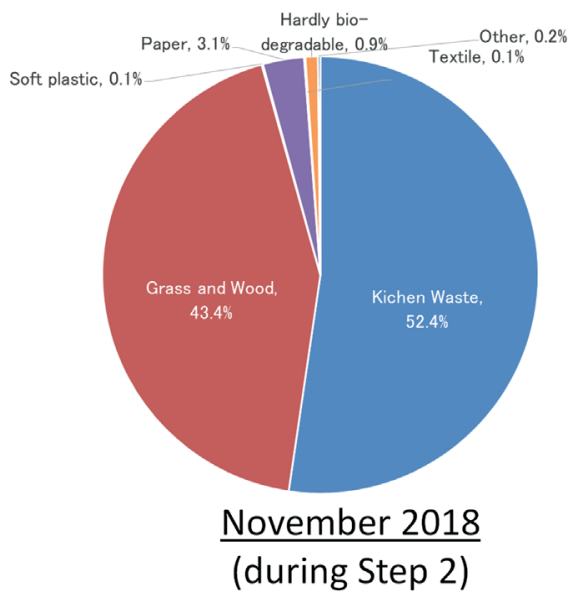

(during Step 2)

FIGURE 7: Changes in biodegradable waste in Zone 03.
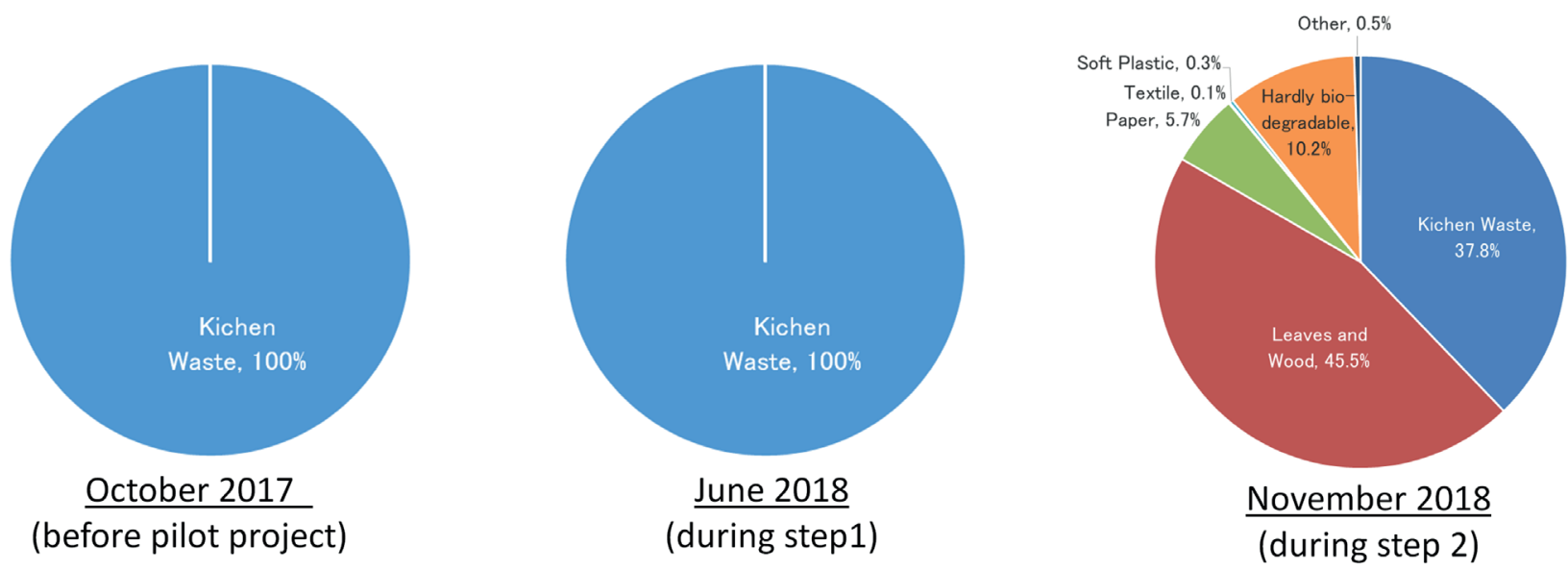

FIGURE 8: Changes in biodegradable waste in Zone 04. 
time of third waste composition survey). Moreover, difficult to degrade waste, which is supposed to be "biodegradable waste" but had been instructed to dispose of as "other waste", was also being separated as "biodegradable waste" by the time of the third waste composition survey. These results show the high degree of acceptance of separate collection by the community as a result of the pilot project. Changes in non-biodegradable waste in Zone 3 and Zone 4 are illustrated in Figure 9 and Figure 10 respectively.

\subsubsection{Outcome of the pilot project}

In KPS, the pilot project was conducted based on the SWM action plan prepared for 2018 to 2022 period, which was developed in cooperation with ReEB Waste and KPS. Table 5 below shows the targets of the action plan and the results thereof. Average amount of separated biodegradable waste being received at the disposal site increased from 2 ton/day in 2017 to 3.4 ton/day in 2018 and 3.5 ton/ day in 2019 , which met the targets of the action plan. The average amount of separated recyclable wastes also increased from 0.1 ton/day in 2017 to 0.2 ton/day in 2018 and 0.4 ton/day in 2019, although this did not yet meet the target of the action plan. Final disposal amount also decreased from 1.4 ton/day in 2017 to 0.3 ton/day in 2018 and 0.3 ton/day in 2019 due to increase of composting and resource recovery at the disposal site. As an element of waste management plan, in year 2017, the open dumpsite was rehabilitated and upgraded to an engineered landfill by ReEB Waste in project spending 35 million Sri Lankan Rupees (US\$ 200,000). Moreover, the lifespan of landfill increased from five years of designed capacity to ten years as a result of reducing the disposal amount through resource recovery activities. The cost of construction per "lifespan year" is thus reduced from approximately 7 million Sri Lankan Rupees (US\$ 40,000)/lifespan year to 3.5 million Sri Lankan Rupees (US\$ 20,000) /lifespan year.

\subsubsection{Discussion}

The main reason for the reduction in the final disposal amount of waste in the KPS pilot project was that biodegradable waste, which accounts for the largest proportion of waste generation, was thoroughly separated at the generation source and intermediately treated. Similar to pilot project in RMC, it was found that distribution of separate bins for biodegradable waste and implementation of discharge and collection rules increases the effectiveness of source separation. However, since KPS did not have sufficient budget and human resources for solid waste management, the primary objective was to separate the biodegradable waste at generation source, and the quantity of valuables (recyclables with market value) separated at source and collected was gradually increased. It is im-

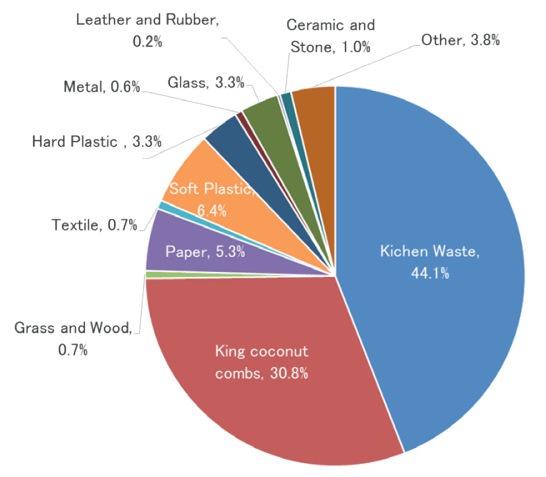

October 2017 (before pilot project)

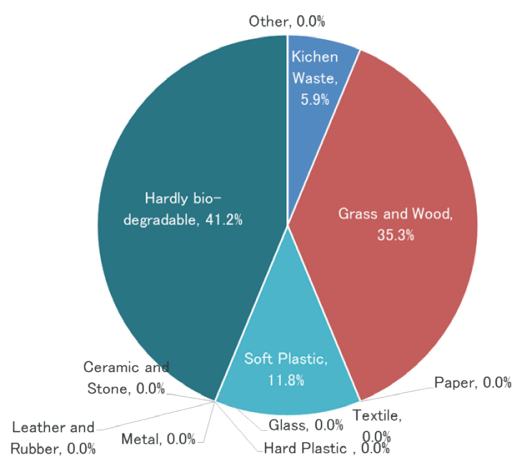

June 2018

(during Step1)

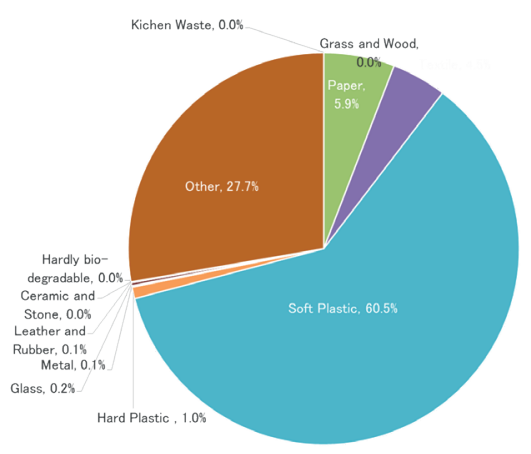

November 2018

(during step 2)

FIGURE 7: Changes in biodegradable waste in Zone 03.

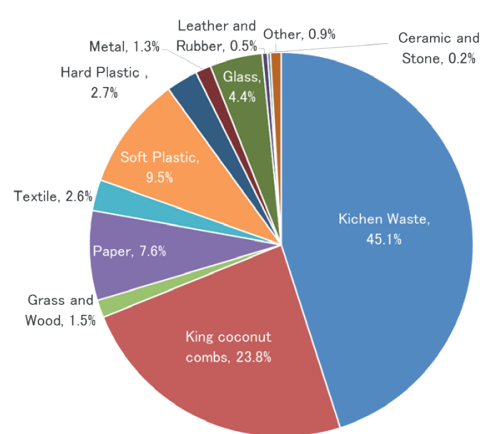

October 2017

(before pilot project)

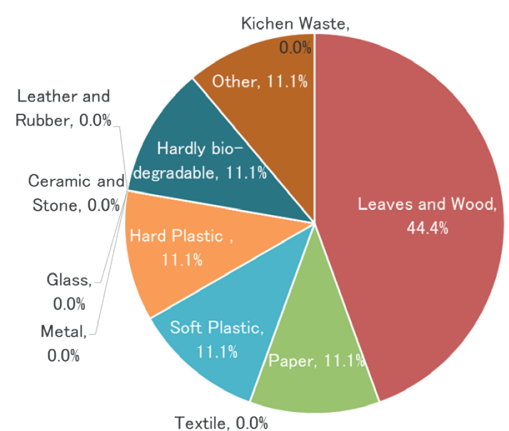

June 2018

(during Step1)

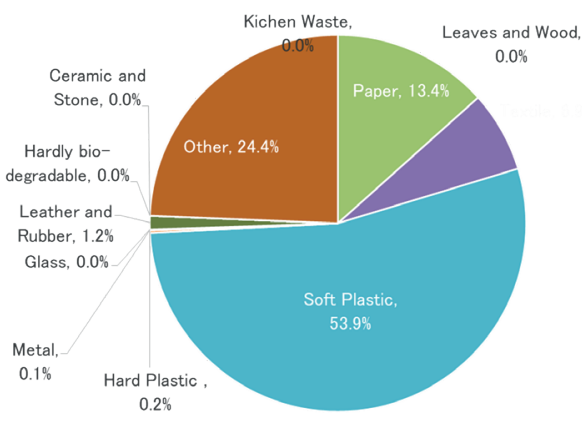

November 2018

(during Step 2)

FIGURE 10: Changes in "other waste" in Zone 04. 
TABLE 5: Targets of Action Plan for KPS and results of average amount.

\begin{tabular}{|c|c|c|c|c|c|c|}
\hline \multirow[b]{2}{*}{ Items } & \multirow[b]{2}{*}{2017} & \multicolumn{2}{|c|}{2018} & \multicolumn{2}{|c|}{2019} & \multirow{2}{*}{$\begin{array}{c}2022 \\
\text { Target }\end{array}$} \\
\hline & & Target & $\begin{array}{l}\text { Result in } \\
\text { November }\end{array}$ & Target & $\begin{array}{c}\text { Result in } \\
\text { March }\end{array}$ & \\
\hline Collection amount of biodegradable waste (ton/day) & 2.0 & 2.5 & 3.4 & 2.9 & 3.5 & 3.9 \\
\hline Collection amount of recyclable waste (ton/day) & 0.1 & 0.7 & 0.2 & 0.7 & 0.4 & 0.7 \\
\hline Final disposal amount (ton/day) & 1.4 & 8.0 & 0.3 & 7.8 & 0.3 & 7.4 \\
\hline
\end{tabular}

portant to determine the number of categories and types of recyclable waste to be separated according to the local authority's implementation capacity, with priority given to the separation of biodegradable waste.

\section{CONCLUSIONS}

The changes of waste composition and final discharge amounts at the disposal sites indicate the pilot projects are contributing to promote $3 \mathrm{Rs}$ in pilot project areas of RMC and KPS. In addition to pilot project areas, local authorities are expanding the promotion of $3 \mathrm{Rs}$ to other areas based on the successful achievement of waste reduction, resources recovery and decrease of final disposal amounts.

It was also found that reduction of waste amount disposed at the final disposal site does not require segregation of waste into many categories, but a remarkable change can be made if waste is separated to two categories; biodegradable waste and non-biodegradable waste. It is also learned that on-site training and immediate instruction and demonstration that combined with distribution of printed instructions by collection workers are more effective way of disseminating the knowledge of waste separation. Also, it was learnt that supply of waste collection bins and bags facilitate rapid establishment of source separation; however, the knowledge dissemination, direct supervision and cooperation of collection workers by accepting only the separated waste during the collection are also important elements to achieve targets of source separated waste collection.

\section{AKNOWLEDGEMENTS}

The authors would like to give special thanks to: Prof. Ken Kawamoto of Saitama University, Japan; Mr. Upali Indrarathna, Deputy Director General of CEA; Ms. Nayana Samaraweera; Mr. L.S.W. Gunasekara, Mr. K.Y.B. Gamagedara, ReEB Waste project coordinator; the staff of RMC and KPS for their support and cooperation in the study. This study was also partially supported by a research grant from JSTJICA Science and Technology Research Partnership for Sustainable Development Program (SATREPS).

\section{REFERENCES}

Ariyawansha, R. T. K., Jayakody, L. N., Gunarathne, H. A. Y. R., Senevirathne, S. A. D. N., Kuruparan, P., Chandrasekara, W. W. C. K., ... Basnayake, B. F. A. (2010a). Estimation of quantum of waste generation and solid waste characterization at Kalmunai Municipal Council (KMC) and Sammanthurai Pradeshiya Sabha (SPS). In Proceedings of Third International Symposium. Sabaragamuwa University of Sri Lanka.

Barton, F. M. A. (1979). Resource recovery and recycling. New York, NY: John Wiley and Sons.

Central Environmental Authority. (2015). Database of solid waste management. 104. Battaramulla, Sri Lanka: Denzil Kobbekaduwa Mawatha.

Basnayake, B.F.A., Popuri, S., Visvanathan, C., Jayatilake, A., Weerasoori, I. and Ariyawansha, R.T.K., (2018). Concerted initiative for planned management of municipal solid waste in target provinces in Sri Lanka. Journal of Material Cycles and Waste Management, pp.1-14.

Irawan B, Sekito T, Dote Y, et al. (2011). Overview of a community-based waste management system and its effect on waste discharge and concerns. Memoirs of the Faculty of Engineering, University of Miyazaki, 40: 181-186.

JICA. (2003). The study on Improvement of Solid Waste Management in Secondary Cities in Sri Lanka-Action Plan for Kandy Final Report Volume V-4A Main Report.

JICA. (2011). Capacity Upgrading Project for the National Solid Waste Management Support Centre Sri Lanka Project Final Report.

JICA. (2016). Data Collection Survey on Solid Waste Management in Democratic Socialist Republic of Sri Lanka Final Report.

JICA. (2019). Pollution Control and Reduction of Environmental Burden in Solid Waste Management Final Report.

JST-JICA( 2016). Pollution Control and Environmental Restoration Techniques for Solid Waste Landfills in Sri Lanka Final Report.

Ministry of Mahaweli Development and Environment. (2018). National Waste Management Policy of Sri Lanka. Retrieved from http:// mmde.gov.lk/web/images/pdf/2018/nationalwastemanagementpolicy-english.pdf

Murase, N., Murayama, T., Nishikizawa, S., and Sato, Y., (2017). Quantitative analysis of impact of awareness-raising activities on organic solid waste separation behaviour in Balikpapan City, Indonesia. Waste Management \& Research, Vol. 35(10), 1013-1022.

Vidanaarachchi, C. K., Yuen, S. T. S., \& Pilapitiya, S. (2005). Municipal solid waste management in the Southern Province of Sri Lanka: Problems, issues challenges. Waste Management (New York, N.Y.), 26(8), 920-930. doi:10.1016/j.wasman.2005.09.013 PMID:16298122

Zurbrugg, C. (2002). Urban Solid Waste Management in Low-Income Countries of Asia: How to Cope with the Garbage Crisis. Proceedings of Urban Solid Waste Management Review Session, Durban, South Africa.

World Bank. (2019). World Bank Open Data: https://data.worldbank. org/country/sri-lanka?view=chart 